\title{
骨セメントによる骨腫瘍の治療経験
}

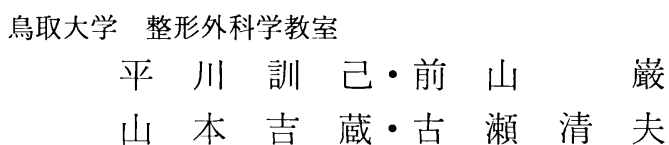

国立米子病院 整形外科

吉川暢一

\section{The Experiences of Bone Tumors Treated with Bone Cement}

By

\author{
K. Hirakawa, I. Maeyama, K. Yamamoto \\ and K. Furuse \\ Department of Orthopedic Surgery, Tottori \\ University School of Medicine
}

\section{Kikkawa}

Orthopedic Clinic, Yonago National Hospital

\begin{abstract}
Bone cement (Palacos $R$ ) was used in the internal fixation and replacement of bone tumors. 2 cases of primaly malignant tumors of bone; malignant xanthofibroma (1) and multiple myeloma (1), 3 cases of metastatic bone tumors; uterus cancer (1) and Grawitz's tumors (2), and 3 cases of benign bone tumors and tumorous conditions; aneurysmal bone cyst (1) and giant cell tumors of bone (2). All patients were given relief of pain and got functional improvement.
\end{abstract}

最近骨セメントは, 人工関節全置換術の発達普及に ともない，その使用頻度が高くなり，固定材料，充填 材料として悪性腫瘍による病的骨折に対しても使用さ れるに至っている.鳥取大学整形外科教室 (以下教室 と略す）でも，最近 2 年間に，切断を拒否した原発性 覀性骨腫瘍をはじめ, 転移性悪性骨腫瘍や, 二次的に 骨移植あるいは人工.関節置換の可能な症例を選び良性 骨腫瘍の一部に骨セメント (Palacos R) を合計 8 例 に充填した.

原発性悪性骨腫煌群, 転移性悪性骨腫瘍群, 良性骨 腫㺍群の 3 群に分けた（表 1 )。

\section{I. 原発性悪性骨腫塆群}

症例 152 才, 女, 農業.

左大腿骨下端の悪性黄色線維腫.

2 年前転倒して左膝関節を打撲したが，特に治療は 受けなかった。昭和 48 年 10 月某病院を受診し, 左大 腿骨の腫瘍を指摘され，当科を紹介されたＸ線的に
は左大腿骨下端に骨透明巣，骨皮質の菲薄化がみら れ, 骨シンチで同部に異常集積がみられた。乙れに対 して病巣搔爬, 自家骨移植を行なった。組織診断は骨 巨細胞腫であった. その後 6 力月でX線的に再発が見 られ，2回目の搔爬，自家骨移植を行なった。組織診 断は骨捠色線維腫であった。 その後約 1 年, ふたたび X線的に再発を珰內た。再三にわたる再発のため, 予 後を考え切断をすすめたが拒否され, 搔爬, 骨セメン 卜充填を行なった。組織䛦断は悪性苳色線維腫で, 骨 セメント允填後 1 年経過する現在, 再発は見られない が, 関節面が少し破壊されている. 転移は無く, 1 本 杖で歩行している.

症例 243 才, 男, 運転手.

多発性骨髄腫.

誘因なく前胸部痛を来たし某病院を受診した後, 当 科へ転医した。発症より受診までの期間は 3 力月であ った。発生部位は朐骨, 両大腿骨, 右上腕骨, 恥骨 
表 1 骨セメント充䪺を行なつた骨腫瘍

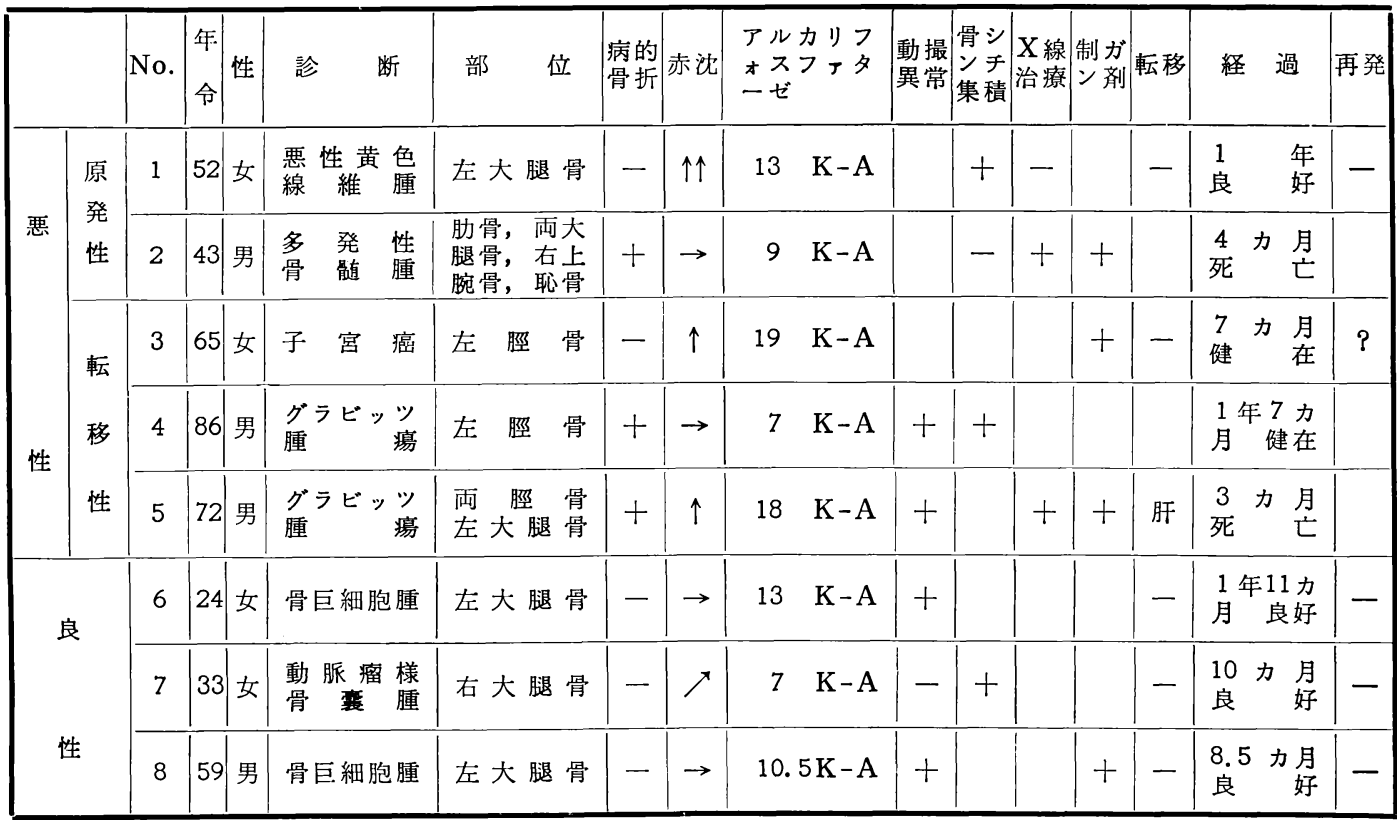

で，大腿骨は病的骨折を起こしており，radiation， エンドキサン, プレドニン投与で治療する一方, 大腿 骨頸部病巣に咀内釘と骨セメントで骨接合術を行なっ た. 術後 4 力月, 死亡.

\section{II. 転移性悪性骨腫源群}

症例 365 才, 女, 主婦.

子宮癌の左䣎骨転移.

子宮癌で radiation を 3 度に分け，合計 $14980 \mathrm{rad}$ 受けている．原発より 6 年 4 力月後, 左脛骨に転移を 来たした．X線的には，周囲に硬化像をともなう骨透 明巣が有り, 試験切除により squamous cell carcinoma の診断を得た後 cryosurgery を行ない, 搔 爬, 骨セメント充筫を行なった。術後 7 カ月, 手術創 より排膿が有り黄色ブドウ球菌を証明された，骨セメ ント周囲に骨吸収が見られ，抗生剤を投与しながら， 切断を含め, 治療を検討している.

症例 486 才, 男.

Grawitz's tumor の右器骨転移.

受臸時, 右舞骨に病的骨折が有り, 骨シンチで異常 集積がみられ，動脈撮影でも血管新生 blood pool が みられた. cryosurgery の後, 骨セメント充填し plate で接合した．組織診断で Grawitz's tumor を証明さ れた. 原発巣の治療は行なわれていないが, 術後 1 年
7 力月健在である.

症例 572 才, 男, 神職.

Grawitz's tumor の両脛骨, 左大腿骨転移.

右脛骨中枢端, 左脛骨下端, 左大腿骨下 $1 / 3$ 亿骨透 明巣が有り，動脈撮影で血管新生，blood pool がみ られる，左脛骨下端および右脛骨上端病巣に cryosurgery, 骨セメント充填を行なった．左鱼骨には plate を併用した。原発巣に対しては左腎摘出術を行ない radiation とエンドキサン投与を行なったが，術後 3 カ月肝転移で死亡した。

\section{III. 良性骨腫演群}

症例 624 才, 女, 店員.

左大腿骨下端の骨巨細胞腫.

バスよりとび降りて，左膝関節痛を来たし，某医を 受搒し, 関節注射を受けた. 2 力月半後, 当科を受診 した・X線的には隔壁を持った大きな骨透明巣が有 り，骨皮質は菲薄になっている（図1）。動脈造影で は血管新生, blood pool がみられた。搔爬, 骨セメ ント充填を行なった．組織診断は骨巨細胞腫であり， 術後 1 年 11 カ月, 骨セメント周囲には clear zone が明嘹で, 関節軟骨の破壊が有るが，関節可動域は $0^{\circ}$ 〜 70 で, 再発も無い（図 2).

症例 733 才, 女, 紡績工. 


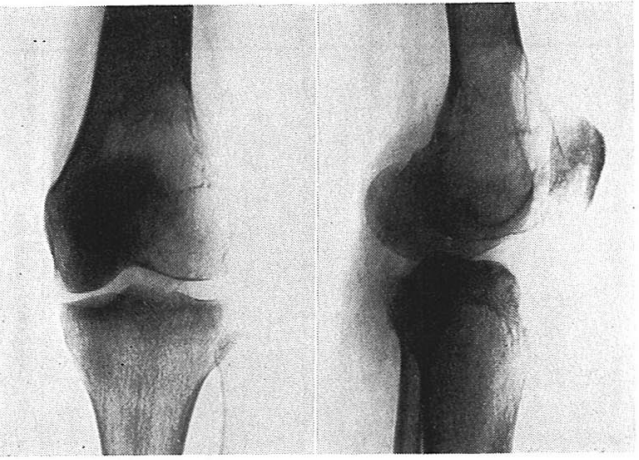

図 1 症例 6 術前 $X$ 線像

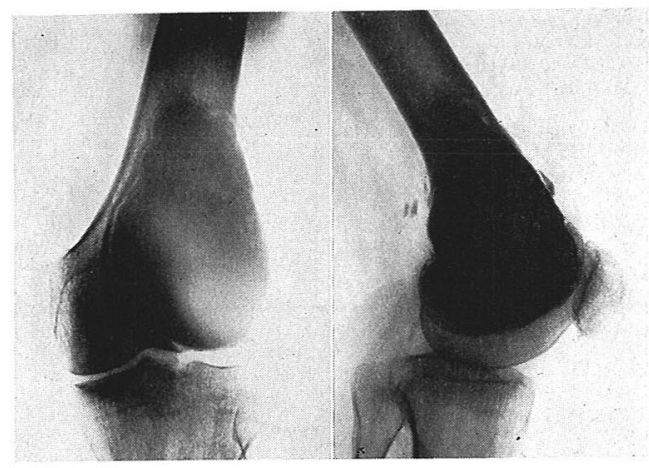

図 2 症例 6 掻爬, 骨セメント充埈後 1 年 11 力

右大腿骨下端の動脈瘤様骨䓰腫.

誘因なく右膝関節痛を来たして 3 年半後に 某医受 䛦，当科紹介された。動脈撮影では特に所見は無い が，骨シンチでは異常集積がみられた。これに対して 搔爬，骨セメント允填を行なった。術後10 力月，再 発は無く, 走るととも出来て経過は良好である.

症例 859 才, 男, 農業 (国立米子例).

左大腿骨下端の骨巨細胞腫.

受誩 2 力月前に運動会で走り, 左膝関節痛を来たし た。X線的に外顆部に骨透明巣が有り骨皮質は菲薄に なっている. 動脈撮影では, 血管新生がみられた。搔 爬，骨セメント充填を行ない，術後 8 力月半で $130^{\circ}$ の可動域を持ち再発は無い。

\section{ま と め}

われわれの教室で最近 2 年間に, 骨腫瘍の治㙩に際 し, 骨欠損部の充填に Palacos $\mathrm{R}$ 在使用した. 原発 性悪性骨腫瘍の外科的治療は, 早期診断, 早期切除市 るいは切断が原則的に行なわれているが, 症例 1 では
悪性化した時点で切断を拒否し，骨セメントを使用し た．術後 1 年の経過は再発も無く，良好である．転移 性悪性骨腫瘍で病的骨折を起しした症例では，すでに 根治治療もおよばず，疼痛の軽減と，支持性を持た せ, 早期より動かせ，患者の ADL 改善をはかり，精 神的な支壳の一助にもなり得たと思う。良性骨腫瘍に 対する治療は，搔爬骨移植が一般的である。しかし骨 巨細胞腫など症例によっては，再発をくり返し，悪性 化の危惧されるものも少なくない，骨目細胞腫で骨セ メント充填後 1 年 11 力月, 8 力月を経過した 2 症例 は, 再発も見られず経過良好である。骨セメントは入 手しやすく, 使い易い充填材料であるが, その毒性, 発癌性が問題にされている．また，重合熱も人工関節 全置換術の際には問題にされるところであるが, Biehl 等が駆血下で骨一Palacor 面の温度を測り $53.2^{\circ} \mathrm{C}$ か ら $65^{\circ} \mathrm{C}$ を測定しているととから, 蛋白凝固温度に達 する可能性が有り, 取り残された腫港細胞死も立分考 光られる。一方関節軟骨への影響も無視出来ない，わ れわれは良性骨腫煌の 3 例については, 二次的に人工 関節あるいは骨移植の可能な症例を選んで骨セメント を充媜した８例中 1 例に感染が起てったが, 手術場 の改善, 骨セメントへ抗生剂の混入等で防げると考光 る. 以上 8 例の経過観察を通して骨セメントは骨腫瘍 にも用いうる材料と思う. 今後経過観察を続けたい.

本研究は文部省科学研究費補助金一般研究 (A) 飞 よるものである.

\section{文献}

1) Bieh1, J. H, et a1.: Arch. Orthop. Unfal1Chir. 78: 62, 1974.

2）松崎昭夫：臨床整形外科, 5:822, 1970.

3) McLauglin, R. E. et al.: J. Bone and Joint Surg. 55-A: 1621, 1973.

4) Scheuba, G.: Arch. Orthop. Unfall-Chir. 65: 330, 1969.

5) Sim, F. H. et al.: J. Bone and Joint Surg. 56-A : 49, 1974.

\section{質 問福岡大学 松猗 昭夫}

覀性腫瘍の病的骨腫に対して使用するのは非常によ いと思うが，良性腫場にはじもから使用された根拠は ? 骨移棫学治療し再発等あった後使ってもよくはな い办。 


\section{追加国立がんセンター 福間 久俊}

私共も癌骨転による病的骨択, 骨髄腫による病的骨 折に対して Bone Cement を使用している. 現在ま で10 例を数えているが術直後より良好な固定が得ら れ外固定の必要がない点など秀れた方法と考える.

良性腫場に対する経験はないが，もし万一再発した 場合の Salvaze operation はどう考えておられます か.

\section{解 答鳥取大整形 平川 訓己}

1) 骨巨細胞腫の大腿骨下端に大きな病巣をつくつ たものは再発しやすい, 従来, 搔爬骨移植が一般的で あるが，われわれは骨セメントを充媜した。治療にあ たっで，どちらが最善か言い切れないと思う。

2 ）症例は二次的に人工関節あるいは骨移植の可能 な症例を選んで行なっている.

\section{解 答}

鳥取大整形 前山 篇

巨大な骨破壊を示す巨細胞腫を骨移植で治癒せしぬ ることはきわめて困難で, 再発の危険が非常に高い. 骨セメントは巨細胞腫の接する骨組織を允分切除しで (準根治的切除), 切除面とクライオサージェリーを 併用したりした。のちに充填しております. 現在まで 再発はなく，また菲薄化した関節軟骨部分の変性もレ 線像でほとんどみられず, 関節可動性もきわめて良好 であります。もし再発があれば，おそらくその発見は 容易で, 早期に関節瘾合術または人工関節など, 他の 方法を二次的に採用するてとが出来ると考えていま す.巨細胞腫に対する骨セメント允填による耐用期間 は予期したより長期であろうと期待している.
発 言鹿大 東 成昭

骨セメントを用いる支持機構の強化という手術は特 に癌転移による病的骨折の予防, 病的骨折に対しても 非常に有力な手段で患者の笭痛除去, 早期離床, 早期 荷重も可能であり今後積極的に行われるべきものと考 える.

\section{追 加庇児島大学整形 柚木紘一郎}

症例 166 才, 女性. 右上腕骨への Adeno-carcinoma の転移例に対し, 病巣の広範切除術後, キュ二 チャ釘を入れ，周囲を骨セメントで充填した。術後，

A. D. L. の改善を見ている.

症例 216 才, 男子. 左腸管に発生した広範な Fibrous Dysplasia に対し，搔爬術後， 毛蓋部に骨移 植を行ない，残った空洞に対し，骨セメントを充填し た. 術後 1 年, 再発の徴候なく, 日常生活も, 大した 障害なく生活している.

追 加北里大学 中島 啓雅 われわれも癌の骨転移に対し, Bone Cement を使 用しているが，その中で特異な症例がある.

乳癌術後 3 年で, 左大腿骨転移を来し, 摇爬, Cryosurgery 後, Bone Cement を允媜し, Blade Plate でとめたが, 2 力月後, セメントと骨との境で, 骨折 を来したので，セメント部を切除し，冷凍保存骨の Massive Bone Graft を行ない, 4 力月後, 骨瘜合 し，転移もなく歩行中の症例を経験したので，追加報 告した。 